\title{
The Prominent Role of Pituitary Adenylate Cyclase- Activating Polypeptide in Spermatogenesis and Function of Spermatozoa: A Mini Review
}

\author{
Muslim Akmal $^{1 *}$, Zulkarnain ${ }^{2}$, Gholib Gholib ${ }^{3}$, Teuku Zahrial Helmi ${ }^{4}$, Sugito \\ ${ }^{1}$ Laboratory of Histology, Faculty of Veterinary Medicine, Universitas Syiah Kuala, Banda Aceh, Indonesia \\ ${ }^{2}$ Laboratory of Biochemistry, Faculty of Medicine, Universitas Syiah Kuala, Banda Aceh, Indonesia \\ ${ }^{3}$ Laboratory of Physiology, Faculty of Veterinary Medicine, Universitas Syiah Kuala, Banda Aceh, Indonesia \\ ${ }^{4}$ Laboratory of Biochemistry, Faculty of Veterinary Medicine, Universitas Syiah Kuala, Banda Aceh, Indonesia \\ ${ }^{5}$ Laboratory of Clinic, Faculty of Veterinary Medicine, Universitas Syiah Kuala, Banda Aceh, Indonesia \\ *Corresponding author.Email: akmal_kh@unsyiah.ac.id
}

\begin{abstract}
Spermatogenesis is a great, complex, and long process. This process take place in the tubulus seminiferus of the testis and consists of three phases i.e. proliferation, meiosis, and spermiogenesis. In proliferation phase, the number of cells were multiplied, while in the meiosis occurs the completion of cleavage to form haploid cells. In the spermiogenesis, the cells perform a morphological change to form the mature gamet that is spermatozoa. Spermatogenesis involves the role of hormones and many molecules resulting the functional spermatozoa which crucial to induce the process of fertilization. Pituitary adenylate cyclase-activating polypeptide (PACAP) is an elderly and multifunctional molecule that necessary in spermatogenesis and the quality of spermatozoa. Many results revealed that PACAP molecule is responsible for male reproduction and fertility. The main objective of this review is to describe the prominent role of PACAP in spermatogenesis and the spermatozoa function.
\end{abstract}

Keywords: pituitary adenylate cyclase-activating polypeptide, reproduction, spermatogenesis, male fertility

\section{INTRODUCTION}

Spermatogenesis is a complicated and long process [1] involves a division and differentiation of spermatogonial stem cells (SCCs) in producing the billions of haploid spermatozoa cells daily $[2,3,4]$ which occurs within tubulus seminiferus of the male testis [5]. SCCs are germinal stem cell which has an important key in maintaining the spermatogenesis a long lifetime of the male [6]. Disturbance in spermatogenesis results a lowquality of spermatozoa [7] that caused the male infertility [8].

The important role of hormonal factors in spermatogenesis has been shown previously [9,10]. Luteinizing hormone ( $\mathrm{LH})$ or testosterone $(\mathrm{T})$ dan follicle stimulating hormone (FSH) are indispensable in regulating the function of testicular/spermatogenesis [11]. LH induces Leydig cells to produce T hormone [10,12]; while within Sertoli cells, FSH cooperate in good-synergy with $\mathrm{T}$ to arrange many signals (molecules) and nutrients needed during spermatogenesis [10]. Therefore, FSH and $\mathrm{T}$ hormone regulate the spermatogenesis indirectly [10]. Dun et al. [13] stated that the several molecules are required in spermatogenesis.

Pituitary adenylate cyclase-activating polypeptide (PACAP) is one of molecule has a key role in regulation of gonadotropin secretion $[14,15]$, system of reproductive [16] spermatogenesis and steroidogenesis [17,18]. Data revealed that some organs particularly brain, testis, and also spermatid cells are rich in the content of PACAP $[19,20]$. PACAP also required in development and function of spermatozoa [21] and also involved in secretion of $\mathrm{T}$ in the culture of Leydig cells [22]. Moreover, Agnese et al. [17] stated that PACAP is a molecule which has a vital role for reproduction.

\section{PITUITARY ADENYLATE CYCLASE- ACTIVATING POLYPEPTIDE (PACAP)}

PACAP is neuropeptide molecule [23,24,25] which expressed extensively in many tissue of the body [26]. PACAP and its receptor is not only express in hypothalamus, however it also expressed in more of the other peripheral organ [27]. Biologically, there are two form of PACAP active such as PACAP 38 dan PACAP 27 [28]. PACAP 27 is originated from the maturation cleavage of PACAP 38 [29] while PACAP 38 is a main form of PACAP which can be found in various tissue of the organ [30]. Agnes et al. [17] stated that there were three receptors of PACAP in many tissues: PAC1, significantly binds with PACAP; VPAC1 and VPAC2, the bond with PACAP and vasoactive intestinal peptide.

PACAP is synthesized as a preprohormone and processed by prohormone convertases such as PC1, PC2, and PC4. PC4 only expressed in testis and ovary, while PC1 and PC2 are not express in these organs [19]. Data revealed that hypothalamus is the organ with a high 
concentration of PACAP, whereas PACAP mRNA discovered in the some organ, including testis [28].

Initially, PACAP isolated from the brain [21]. However, a high concentration of PACAP has been found in the testis [30] and also expressed significantly in the spermatids of rats [19] as well as in the acrosome of spermatozoa. This indicated that PACAP have a critical role in the growth and function of spermatozoa [21], and assumed to have the role in mediating the interaction between spermatozoa and cumulus cells in supporting the fertilization process [31].

PACAP involving spermatogenesis in four phases: (i) Expressed in immature of the spermatozoa, (ii) Involved in the late of spermiogenesis, (iii) Induce the activity in supporting the Sertoli cells, and (iv) Regulate the Leydig cells in secretion of T [22]. Chun_Mei et al. $\{32\}$ reported that PACAP mRNA was expressed in the testis and epididymis of the rats. In the testis, particularly in spermatocyte and round spermatid cells, the expression of PACAP mRNA was observed on day 20 after birth and then increase rapidly until maximum level on day 60 . Meanwhile in epididymis, expression of PACAP mRNA was visible on day 10 after birth and increase in a high level from day 40 [32]. Moreover, in the normal testes, immunoreactivity of PACAP has been found in the cells of spermatogonia and spermatid [33].

\section{THE ROLE OF PACAP}

PACAP is a multifunctional molecule that is required to stimulate cyclic adenosine monophosphate (cAMP) production in anterior of pituitary cells [34], while cAMP itself is a compound which is needed to activate the steroidogenesis [35] and a good regulator in induction of Leydig cells function [36]. Although PACAP was ineffective in stimulating the cAMP production in Sertoli cells compared to FSH [37], PACAP showed the ability to substitute FSH to induce the level cAMP that was required in spermatogenesis [26].

Spermatozoa motility in the human male is influenced by PACAP and involving the growth and functional of spermatozoa. Lack in PACAP concentration causes badeffects on motility and morphology of the spermatozoa [21]. Study on male rats revealed that PACAP is a molecule that responsibility to the decrease of the male mice fertility [16]. Nakamura et al. [33] showed that in human, PACAP have a significant role in spermatogenesis and the growth of testicular germ cell tumor.

The scientists have found a signaling pathway in describing the role of PACAP in spermatogenesis. Binding PACAP to its receptor (PAC1) will activate the enhancement intracellular concentration of PACAP which caused the activation of protein kinase A (PKA). Ser/Thr phosphatase (PP2A) arranged the phosphorylation of downstream PKA target reversibly.
PP2A can induce the dephosphorylation of Sox9 transcription factor until it be able to modify the expression or activation of Sox10. On the other hand, PKA can regulate the phosphorylation of extracellular signal-regulated kinases $1 / 2$ (ERK1/2) that followed by p38 activation. The main target of Sox 9 transcription factor is collagen type IV and collagen type IV or testatin. All of these are responsible in phosphorylation some the event that regulate proliferation, motility, and establishment of the blood-testis barrier [16]. The results showed that PKA needed in capacitation of mammalian spermatozoa [38], while ERK pathway involved in the functional of human spermatozoa [39] and it also required in the regulation of capacitation and acrosome reaction on the mammalian spermatozoa [40]. In addition, the facts showed that in human, expression of collagen type IV causes the thickening of basic membrane of tubules seminiferous testes which relating with spermatogenesis [41]. The study also showed that defect in testatin expression on mice relating with the development disorder of fetal Sertoli cells [42].

The previous study showed that administration of epididymis extract which in rich concentration of PACAP have potency in the increase of T concentration [43], FSH, LH, and follicle stimulating hormone-receptor expression [44], estrogen [45], dihydrotestosterone [46] and capable to increase the quality of spermatozoa in male local goat [47]. Furthermore, the study in male chicken showed that administration of epididymis and testicular extract combination influence the concentration of androgen receptor, protein kinase A [48], PACAP, protamine 1 and increase significantly the concentration of $T$ [49]. Protamine has a vital role as a check point spermatogenesis [50], in which protamine 1 affects the quality of spermatozoa in the bull [51] and mice [52], while protamine 2 is required in inducing spermatogenesis and spermatozoa quality in the male rats [7]. Furthermore, both protamine 1 dan 2 plays important role in functional and quality of the human spermatozoa [53]. Generally, the role of PACAP in spermatogenesis and spermatozoa function is presented in Figure 1.

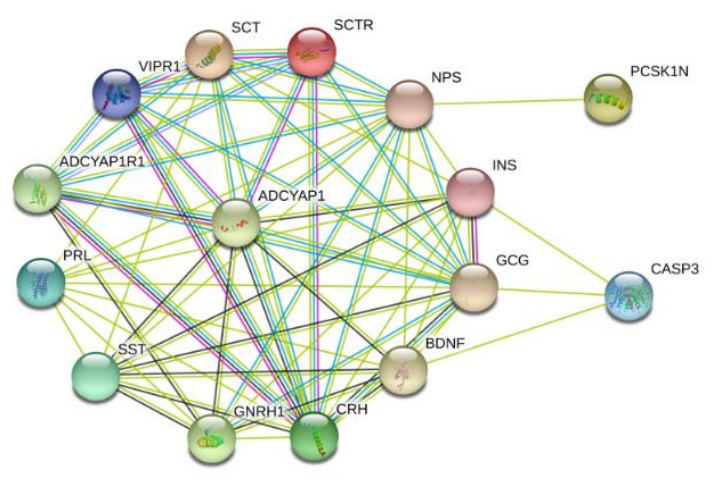

Figure 1 PACAP Protein Network 
PACAP protein has linkage to many proteins in involving the spermatogenesis and spermatozoa function. Figure 1 which was obtained from STRING-DB showed that the interaction of PACAP (ADCYAP1) to its receptor and some of the other molecules involve the expression of PACAP (up-regulation and downregulation). Lines of interaction with colors showed that some type of interaction which gained and proved from several of literature source. The numbers of line interaction between protein indicated the confidence score of a high interaction. However, the scoring did not show the strength or interaction of specifity.

PACAP protein have the multifunctional role as a hormone, neurotransmitter, neuromodulator, vasodilator and neurotropic factor caused it affect and influenced by many molecules protein as shown in the picture. ADCYAP1 (pituitary adenylate cyclase-activating polypeptide), ADCYAP1R1 (pituitary adenylate cyclaseactivating polypeptide type 1 receptor), VIPR1 (vasoactive intetstinal polypeptide receptor 1), SCT (secretin), SCTR (secretin receptor), NPS (neuropeptide), INS (Insulin), GCG (glucagon), BDNF (brain-derived neurotrophic factor), $\mathrm{CRH}$ (corticoliberin), GNRH1 (Progonadoliberin-1), SST (somatostatin), PRL (prolactin) PCSK1N (ProSAAS), CASP3 (Caspase-3). Data was obtained from String-DB.

\section{CONCLUSION}

PACAP is an elderly and multifunctional molecule which express in many tissue of the body particularly in the brain and testis. This molecule has a significant role in spermatogenesis and function of spermatozoa that essential for fertilization process.

\section{AUTHORS' CONTRIBUTIONS}

MA, Z, G, TZH, and S, are equally contributed to this article.

\section{ACKNOWLEDGMENTS}

All authors would like to thank the Rector of Universitas Syiah Kuala for all supports.

\section{REFERENCES}

[1] S.A. Ramm, L. Scharer, J.J. Wistuba, Sperm competition and the evolution of spermatogenesis, Mol. Hum. Reprod. 20(12) (2014) 1169-1179.

[2] L. Dong, S.G. Kristensen, S. Hildorf, M. Gul, E. Clasen-Linde, J. Fedder, E.R. Hoffmann, D. Cortes, J. Thorup, C.Y. Andersen, Propagation of spermatogonial stem cell-like cells from infant boys. Front. Physiol. 10(1155) (2019) 1-11.
[3] A.P. Fayomi, K.E. Orwig, Spermatogonial stem cells and spermatogenesis in mice, monkeys and men. Stem. Cell. Res. 29 (2018) 207-214.

[3] F. Savvulidi, M. Ptacek, K.S. Vargova, L. Stadnik, Manipulation of spermatogonial stem cells in livestock species. J. Anim. Sci. Biotechno., 10(46) (2019) 1-18.

[4] C. Staub, L. Johnson, Review: Spermatogenesis in the bull. Animal 12(s1) (2018) s27-s35.

[5] D.G. De Rooij, The nature and dynamics of spermatogonial stem cells, Development 144 (2017) 3022-3030.

[6] M. Akmal, M.A. Aulanni'am, S.B. Widodo, B.B. Sumitro, Purnomo, Widodo, The important role of protamine in spermatogenesis and quality of sperm: A mini review, Asian Pac. J. Reprod. 5(5) (2016) 357-360.

[7] F. Tüttelmann, C. Ruckert, A. Röpke, Disorders of spermatogenesis, Med. Genet. 30(1) (2018) 12-20.

[8] N. Sofikitis, N. Giotitsas, P. Tsounapi, D. Baltogiannis, D. Giannakis, N. Pardalidis, Hormonal regulation of spermatogenesis and spermiogenesis, J. Steroid. Biochem. Mol. Biol. 109(3-5) (2008) 323-330.

[9] O.O. Oduwole, H. Peltoketo, I.T. Huhtaniemi, Role of follicle-stimulating hormone in spermatogenesis, Front. Endocrinol. (Lausanne) 9 (2018) 763.

[10] S. Ramaswamy, G.F. Weinbauer, Endocrine control of spermatogenesis: Role of FSH and LH/testosterone, Spermatogenesis, 4(2) (2014) e996025.

[11] I. Huhtaniemi, Mechanisms in endocrinology: hormonal regulation of spermatogenesis: mutant mice challenging old paradigms, Eur. J. Endocrinol. 179(3) (2018) R143-R150.

[12] M.D. Dun, R.J. Aitken, B. Nixon, The role of molecular chaperones in spermatogenesis and the post-testicular maturation of mammalian spermatozoa, Hum. Reprod. Update 18(4) (2012) 420-435.

[13] R. Counis, J.N. Laverrière, G. Garrel-Lazayres, J. Cohen-Tannoudji, S. Larivière, C. Bleux, S. Magre, What is the role of PACAP in gonadotrope function?, Peptides 28(9) (2007) 1797-1804.

[14] W. Zheng, C.M. Grafer, L.M. Halvorson, Interaction of gonadal steroids and gonadotropinreleasing hormone on pituitary adenylate cyclaseactivating polypeptide (PACAP) and PACAP receptor expression in cultured rat anterior pituitary Cells, Reprod. Sci. 21(1) (2014) 41-51. 
[15] D. Reglodi, S. Cseh, B. Somoskoi, D. Fulop, E. Szentleleky, V. Szegeczki, A. Kovacs, A. Varga, P. Kiss, H. Hashimoto, A. Tamas, A. Bardosi, S. Manavalan, E. Bako, R. Zakany, T. Juhasz, Disturbed spermatogenic signaling in pituitary adenylate cyclase activating polypeptide deficient mice, Reproduction, 155(2) (2018) 129-139.

[16] M. Agnese, S. Valiante, L. Rosati, P. Andreuccetti, M. Prisco, Pituitary adenylate cyclase-activating peptide (PACAP) and PAC1 receptor in the testis of cartilaginous fish Torpedo marmorata: A molecular and phylogenetic study. Gen. Comp. Endocrinol. 191 (2016) 26-35.

[17] M. Prisco, L. Rosati, M. Agnese, S. Aceto, P. Andreuccetti, S. Valiante, Pituitary adenylate cyclase-activating polypeptide in the testis of the quail Coturnix coturnix: Expression, localization, and phylogenetic analysis, Evol. Dev (2019) pp. 112.

[18] M. Li, M. Mbikay, A. Arimura, Pituitary adenylate cyclase-activating polypeptide precursor is processed solely by prohormone convertase 4 in the gonads, Endocrinology, 14(10) (2000) 3723-3730.

[19] M. Agnese, S. Valiante, F. Angelini, V. Laforgia, P. Andreuccetti, M. Prisco. Pituitary adenylate cyclase-activating polypeptide and its receptor PAC1 in the testis of Triturus carnifex and Podarcis sicula, Gen. Comp. Endocrinol, 168(2) (2010) 256261.

[20] R. Brubel, P. Kiss, A. Vincze, A. Varga, A. Varnagy, J. Bodis, L. Mark, E. Jambor, E., Maasz, H. Hashimoto, Z.S. Helyes, G. Toth, A. Tamas, M. Koppan, D. Reglodi, (2012) Effects of pituitary adenylate cyclase activating polypeptide on human sperm motility, J. Mol. Neurosci. 48(3) (2012) 623630.

[21] F. El-Gehani, M. Tena-Sempere, I. Huhtaniemi, Evidence that pituitary adenylate 570 cyclase activating polypeptide is a potent regulator of fetal rat testicular steroidogenesis, Biol. Reprod. 63(5) (2000) 1482-1489.

[22] A. Rivnyak, P. Kiss, A. Tamas, D. Balogh, D. Reglodi, Review on PACAP-induced transcriptomic and proteomic changes in neuronal development and repair, Int. J. Mol. Sci, 19 (2018) 1020 .

[23] T. Hirabayashi, T. Nakamachi, S. Shioda, Discovery of PACAP and its receptors in the brain, J. Headache. Pain 19(1) (2018) 28.

[24] T. Nakamichi, A. Tanigawa, N. Konno, S. Shioda, K. Matsuda, Expression patterns of PACAP and
PAC1R genes and anorexigenic action of PACAP1 and PACAP2 in Zebrafish, Front. Endocrinol. 10(227) (2019) 1-9.

[25] P.B. Daniel, J.F. Habener, Pituitary adenylate cyclase-activating polypeptide gene expression regulated by a testis-specific promoter in germ cells during spermatogenesis, Endocrinology 141(3) (2000) 1218-1227.

[26] A. Oride, H. Kanasaki, S. Kyo, Role of pituitary adenylate cyclase-activating polypeptide in modulating hypothalamic-pituitary system, Reprod. Med. Biol. (2018) pp. 1-8.

[27] J. Hannibal, J. Fahrenkrug, Expression of pituitary adenylate cyclase activating polypeptide (PACAP) gene by rat spermatogenic cells, 55(1) (1995) 111 115.

[28] A. Miyata, L. Jiang, R.D. Dahl, C. Kitada, K. Kubo, M. Fujino, N. Minamino, A. Arimura, Isolation of a neuropeptide corresponding to the N-terminal 27 residues of the pituitary adenylate cyclaseactivating polypeptide with 38 residues (PACAP38). Biochem. Biophys. Res. Commun. 170 (1990) 643-648.

[29] A. Arimura, A. Somogyvári-Vigh, A. Miyata, K. Mizuno, D.H. Coy, C. Kitada, Tissue distribution of PACAP as determined by RIA: highly abundant in the rat brain and testes, 129(5) (1991) 2787 2789.

[30] I. Tanii, T. Aradate, K. Matsuda, A. Komiya, H. Fuse, PACAP-mediated sperm-cumulus cell interaction promotes fertilization. Reproduction 141(2) (2011) 163-171.

[31] L.V. Chun-Mei, C. Dan-Ling, W. Zhao, H. Zhu, Pituitary adenylate cyclase-activating polypeptide mRNA expression in rat testis and epididymis during postnatal development and experimental cryptorchidism. Mol. Med. Rep. 4 (2011) 793-798.

[32] K. Nakamura, T. Nakamichi, K. Endo, K. Ito, T. Machida, T. Oka, M. Hori, K. Ishizaka, S. Shioda, Distribution of pituitary adenylate cyclaseactivating polypeptide (PACAP) in the human testis and in testicular germ cell tumors. Andrologia 46(5) (2014) 465-471.

[33] D. Vaudry, B.J. Gonzalez, M. Basille, L. Yon, A. Fournier, H. Vaudry, Pituitary adenylate cyclaseactivating polypeptide and its receptors: from structure to functions, Pharmacol. Rev. 52(2) (2000) 269-324.

[34] P.R. Manna, S.P. Chandrala, Y. Jo, D.M. Stocco, cAMP-independent signaling regulates steroidogenesis in mouse Leydig cells in the 
absence of StAR phosphorylation. J. Mol. Endocrinol. 37 (2006) 81-95.

[35] A. Lacombe, V. Lelievre, C.E. Roseli, W. Salameh, L. Yan-he, G. Lawson, M. Jean-Marc, J.A. Waschek, E. Vilain, Delayed testicular aging in pituitary adenylate cyclase-activating peptide (PACAP) null mice. Proc. Natl. Acad. Sci. 103(10) (2006) 3793-3798.

[36] J.J. Heindel, C.J. Powell, C.S. Paschall, A. Arimura, M.D. Culler, A novel hypothalamic peptide, pituitary adenylate cyclase activating peptide, modulates Sertoli cell function in vitro, Biol. Reprod. 47(5) (1992) 800-806.

[37] C. Stival, C. Ritagliati, X. Xinran Xu, M.G. Gervasi, G.M. Luque, C.B. Graf, J.L. De la VegaBeltrán, N. Torres, A. Darszon, D. Krapf, M.G. Buffone, P.E. Visconti, D. Krapf, Disruption of protein kinase a localization induces acrosomal exocytosis in capacitated mouse sperm, JBC 293 (2016) 9435-9447.

[38] E. de Lamirande, C. Gagnon, The extracellular signal-regulated kinase (ERK) pathway is involved in human sperm function and modulated by the superoxide anion, Mol. Hum. Reprod. 8(2) (2002) 124-135.

[39] L.R. Ben-Navi, T. Almog, Z. Yao, R. Seger, Z. Naor, A-kinase anchoring protein 4 (AKAP4) is an ERK1/2 substrate and a switch molecule between cAMP/PKA and PKC/ERK1/2 in human spermatozoa, Sci. Rep-UK, 6 (2016) 37922.

[40] M. Dobashi, M. Fujisawa, I. Naito, T. Yamazaki, H. Okada, S. Kamidono, Distribution of type IV collagen subtypes in human testes and their association with spermatogenesis, Fertil. Steril. 80(2) (2003) 755-760.

[41] V. Töhönen, J. Frygelius, M. Mohammadieh, U. Kvist, L.J. Pelliniemi, K. O’Brien, K. Nordqvist, A. Wedell, Normal sexual development and fertility in testatin knockout mice. Mol. Cell. Biol. 25(12) (2005) 4892-4902.

[42] M. Akmal, T.N. Siregar, S. Wahyuni, S. Exploration of the potency of epididymal ductus as inductor of sperm quality: An effort to increase the population and genetic quality of local goat. Research Report of "Postgraduate Research" Year 1, Research Institute of Syiah Kuala University, Darussalam, Banda Aceh, 2014.

[43] M. Akmal, Syafruddin, M Abrar, Exploration of the potency of epididymal ductus as inductor of sperm quality: An Effort to Increase the Population and genetic quality of local goat. Research Report of
"Postgraduate Research" Year 2, Research Institute of Syiah Kuala University, Darussalam, Banda Aceh, 2015.

[44] M. Akmal, T.N. Siregar, S. Wahyuni, M.K. Nasution, M. Abrar, Syafruddin, Administration of epididymis extract have potency to increase the concentration of estrogen in male local goat. National Seminar Proceeding of Research Result, PPM of Bogor Agricultural Institute (IPB), Bogor, 2016, pp:153-160.

[45] N. Yuliansyah, M. Akmal, T.N. Siregar, S. Wahyuni, M. Abrar, Syafruddin, G. Gholib, F. Athaillah, The administration of epididymis extract increased the testosterone concentration without affects the dihydrotestosterone concentration in local male goat. Int. J. Trop. Vet. Biomed. Res. 2(2) (2017) 1-6.

[46] M. Akmal, T.N. Siregar, S. Wahyuni, M. Hambal, Sugito, Amiruddin, Syafruddin, Roslizawaty, Zainuddin, M. Adam, Gholib, C.D. Iskandar, Rinidar, N. Asmilia, Hamny, Joharsyah, Suriadi, Epididymis extract has potency to increase the sperm quality of local male goat, J. Ked. Hewan 9(2) (2015) 168-173.

[47] M. Akmal, Gholib, M.K. Nasution, S. Wahyuni., Rinidar, D. Masyitha, M.A. Yaman. The concentration of androgen receptor and protein kinase $\mathrm{A}$ in male chicken following the administration of a combination of the epididymis and testicular extracts, Vet. World, 2020, 13(8):1594-1598.

[48] M. Akmal, Gholib, Rinidar, Fitriani, T.Z. Helmi, Sugito, M. Isa, Nurliana, S. Wahyuni, Dasrul, M.A. Yaman, The concentration of testosterone, pituitary adenylate cyclase-activating polypeptide, and protamine 1 in the serum of male chicken following administration of epididymis and testicular extracts and their combination, Vet. World, 12(7) (2019) 1101-1107.

[49] D.T. Carrell, B.R. Emery, S. Hammoud, Altered protamine expression and diminished spermatogenesis: what is the link?, Hum. Reprod. Update 13(3) (2007) 313-327.

[50] S. Dogan, P. Vargovic, R. Oliveira, L.E. Belser. A. Kaya, A. Moura, P. Sutovsky, J. Parrish, E. Topper, E. Memili, Sperm protamine-status correlates to the fertility of breeding bulls. Biol. Reprod. 92(4) (2015) 92

[51] N. Takeda, K. Yoshinaga, K. Furushima, K. Takamune, Z. Li, A. Shin-ichi, A. Shin-ichi, Y. Ken-ichi, Viable offspring obtained from Prm1- 
deficient sperm in mice. Sci. Rep-UK, 6 (2016) 27409.

[52] H. Amor, A. Zeyad, M.S. Bakry, A.M.H. Bosilah, H.B. Ali, M.E. Hammadeh, Protamine ratio as predictor of the fertility potential of sperm by couple undergoing ICSI. IJWHR 6(4) (2018) 400409. 